\title{
Position of Satua or Bali Myth in Socio-Cultural Change in Society
}

\author{
I Nengah Duija ${ }^{1}$, Kadek Aria Prima Dewi PF $^{2}$ \\ \{nengahduija@yahoo.com ${ }^{1}$,primadewipf@gmail.com ${ }^{2}$ \} \\ ${ }^{1,2}$ Institut Hindu Dharma Negeri Denpasar, Bali, Indonesia
}

\begin{abstract}
Bali as a tourist destination is faced with several environmental issues such as: (1) the occurrence of seizure or sharp competency of limited resource use, (2) pressure on the environment in the form of coastal erosion and abrasion, land pollution by plastics, water by residual pesticide pollutants, soap, dyes, hot water, air pollution, careless billboards, (3) cultural dislocations in the form of consumerism and love to imitate what is done by tourists, especially by the younger generation, (4) the distribution of uneven economic benefits between one with the other area, between those who have and those who do not, so that it raises sharp social jealousy, and (5) weakness in management is also the cause of the emergence of issues and problems mainly associated with coordination problems in setting a policy. Based on these reflections, thoughts are tried to be directed at groups of people who in their own way overcome the problem through local wisdom (oral tradition) that they have.
\end{abstract}

Keywords: Satua, Bali Myth, Environment, Socio-Cultural Change of Society

\section{INTRODUCTION}

Bali as a tourist destination is faced with several environmental issues such as: (1) the occurrence of seizure or sharp competency in the use of limited resources, such as agricultural land, forests and water, (2) pollution, (3) cultural dislocations in the form of consumerism and love to imitate what is done by tourists, (4) the distribution of unequal economic benefits between regions with one another, between rich and poor people, and (5) management weakness is also the cause of the emergence of issues and problems mainly associated with coordination problems in establishing a policy.

The issues and problems should get the attention of all components of the Balinese society, so that a holistic solution can be found that refers to the Tri Hita Karana concept. Although Bali has a philosophical foundation Tri Hita Karana in managing changes to problems and issues as above, but now in reality the Balinese have experienced a change in character, as an impact of modernization and globalization. Every community has vary tradition roots based on geography, customs, language, religion and so on. A tradition can be born from the appreciation of society towards the natural environment (read: theo-ecology) as a preliminary answer to the mystery of the surrounding environment. According to [1] in an oral tradition (oral literature) cultural facts can be explored, such as: geneological systems, cosmology and cosmogony, history, philosophy, ethics, morals, knowledge systems and linguistic rules. The disclosure of meaning 
in a holistic manner is the cultural facts as the reason why the meaning of an oral tradition is so important today (modern times).

Oral traditions are generally well maintained by the people of Bali Aga, namely people who are less affected by Javanese Hindu culture than Majapahit and have their own structure. The Bali Aga people generally inhabit villages in mountainous areas, such as: Sembiran, Cempaga Sidatapa, Pedawa, Tigawasa in Buleleng Regency and Tenganan Pegringsingan village in Karangasem Regency [2]. Outside those area, there are also oral traditions which are still well maintained but are still related to socio-cultural, especially environmental communication problems called cosmology and cosmogony aspects as models of vertical communication (symbolic communication) and horizontal (communication with language) implied in myths referred to, namely "I Ratu Ayu Mas Mampeh" a myth that tells about the power of Ida Bhatari Batur as the ruler of water. These myths are anthropologically the production of local culture which is used as a form of environmental communication to local residents and outside communities.

The myths in the local language of Bali are categorized as traditional Balinese literary forms known as Satua Bali. Satua Bali (Balinese folktales) is an embodiment of Hindu values which aim to give "understanding" to the conscience and behavior to children as early as possible[3]. Therefore, Satua Bali is not just a tradition of solace, but is able to become the topic of environmental communication in various situations as a form of strengthening the existence of the surrounding environment, which is often damaged by humans themselves, even though the positive law that governs it is clear. Satua Bali (folktales) is a variety of traditional Balinese literature.

Myths contain values that serve to help humans regulate and understand complex systems and phenomena. It can be a starting point for the recovery and management of degraded ecosystems. In this respect, the myths about preserving the environment must be maintained [3]. Satua Bali is a Balinese traditional folklore has a unique teaching of values and culture. However, Satua Bali is lagging behind due to human attitudes and technological advances. Balinese people, who consider a folklore as a myth which has no logic, contribute to Satua Bali's degradation. This attitude resulted in the legacy of the ancestral heritage is being increasingly forgotten and continues to disappear brought about by modernity flows [4]. Every tradition or ritual activity, which is carried out continuously in Bali, is based on the teachings of Hinduism which are packaged in myths, one of which is the myth of the Satua Bali. In fact, religious ceremonies relating to the preservation of the environment are still actively carried out, however they are not seen as a reference for the community to behave positively in the environment. Thus there is an imbalance between das sollen (what is expected) with das sein (what happens). Based on this phenomenon, a study of the position of folklores or the myths of Bali is carried out in the midst of the swift changes in adult socio-cultural Balinese society.

\section{METHOD}

This research is a qualitative research that produces data or information that can describe social reality and related events in people's lives. This research was supported by the method of content analysis. The content in the content analysis method consists of two types, namely the latent content and communication content. Latent content is the content contained in documents and texts, while the communication content is a message contained as a result of communication that occurs. The latent content is the content referred to the author while the communication content is the content as manifested in the relationship of manuscripts to consumers [5]. Based on the problems investigated, this study was classified as a case study. The purpose of the case 
study is to provide a detailed description of the background, traits and characteristics that are typical of the case, or the status of the individual, which then from the typical traits will be made into a general matter. This research was included in the case study research because this study focused on folktale texts that had been determined and did not produce the same study if applied to other folk tale texts.

\section{RESULT AND DISCUSSION}

\subsection{Position of Satua or Bali Myth in Changes in Social Community}

Social change is part of cultural change [6]. Changes in culture include all parts, which include art, science, technology, philosophy and others. Cultural change scope is wider than social change. However, in practice in the field both types of changes are very difficult to separate. Social change and cultural change have the same aspects, namely, both are related to a way of accepting new ways or an improvement in the way a society meets its needs [7].

Following the description above, social change is part of a culture which includes art, science, philosophy and others. Both of these changes cannot be separated, and in this context, changes also occur in various aspects of Balinese life. One of them is the position and existence of Satua Bali as a speech media that has a variety of meaning content which has now begun to be forgotten by the Hindu community in Bali, especially in rural areas.

The previous description states that satua Bali or folktale with their variants appeared in various regions in Bali. Its existence is certainly a medium of education and educates the public in maintaining the existence of natural ecosystems. Because rural communities in Bali in ancient times were very dependent on nature and directly in contact with nature. In addition, Balinese people have a harmony relationship with nature since long time ago, so that the life of rural Balinese people from the past was very dependent on nature. Such a culture of rural communities is clarified and / or reaffirmed by the concept of Tri Hita Karana, so that the nature and human nature of rural Bali has a significant connection.

Based on this, in some areas in Bali, there can still be a variety satua or mythologies that implicitly have a certain meaning, namely maintaining the harmony of human relations with nature. Keeping the continuity of nature in order to stay sustainable through speech media in the form of narrative stories is one of the wisdom possessed by wise elders in ancient times. Through the story, understanding how important nature is as a source of life will seep in the minds of the Balinese rural community.

The position of satua Bali which is so important but in the present era is increasingly distorted by the flow of modern post, so that Satua Bali is only considered as mythology without meaning. In addition, the rapid flow of globalization technology has increasingly made the Satua Bali buried. Not dismissing, Balinese people as well as the younger generation are more interested in imported stories that are packaged in interesting ways. Satua Bali as the noble legacy of Balinese people in which there are various meanings and values and various local wisdom in the future will be increasingly abandoned by the Balinese themselves.

Based on this, position of Satua Bali in the midst of socio-cultural changes is very worrying. Here are some of them that still exist and are still used as a basis in interpreting the existence of ecology.

\subsubsection{Satua Puncak Rangda in Tabanan Regency}

Based on interviews with Pan Dewi (September 13, 2012) related to the existence of forests in Puncak Rangda, Selemadeg Barat District, Tabanan Regency. Once before the establishment of the Tabanan kingdom, the Tabanan area was a very thick forest, and one of the 
famous ones was Rangda Hill. According to the story of the elders around Bukit Rangda mentioning that the area was a kingdom of jinns, demons, gamang, memedi and other ghosts whose faces were very scary. In Balinese it is often said to resemble Rangda, which is big, tall, fanged, dangling hair, tongue out, teeth and eyes large and thirsty to kill.

Formerly on the slopes of the mountain there was a village led by a Prebekel. He had a very beautiful daughter. King Tabanan wanted to marry Prebekel's daughter to become his wife. But by the father feeling sorry for his daughter being married by the King. This is because the king had many wives. Many messengers from the king were ordered to apply for the Prebekel child. But none of them succeeded in getting the intended prebekel child. With the power of the King and his enormous influence the village wanted to be attacked. The King's order was that anyone who fights must be killed. This was also heard by Prebekel and his inhabitants. So it made the residents and Prebekel felt worried. Then Prebekel and the residents set a strategy to defeat the arbitrary power of the king.

Residents and Prebekel did not want war to happen. Finally the strategy to defeat the king was that the residents gathered to perform the Nyeraya or semadi ritual on the hill. After a long time and devoted to doing meditation, the entire population turned into spirits, villages until the entire population disappeared. The king with soldiers who were about to attack the residents became confused because everything turned into a forest with large wooden trees.

The soldiers were very scared because every wood felled turned into a creepy spirit creature. The warriors ran while shouting rangda, rangda, rangda. So until now the hill is called Bukit Rangda. Communities around Bukit Rangda believe that the Bukit Rangda area is still inhabited by these spirit creatures because the forest is a house of ghost and other spirits. The people around Bukit Rangda believe in a myth that anyone who enters the Rangda Hill area should not cut tree branches, bring fire, let alone cut down wood that is around Bukit Rangda.

According to the public belief that the wood is perbekel and the residents who have transformed themselves into tree trunks. When entering the Rangda Hill forest cutting branches or cutting down trees means hurting or killing prebekel and his inhabitants. So that, other residents who have turned into wood will be angry and demand revenge against those who doing this. Therefore, until now people who enter or pray in Bukit Rangda do not dare to pick or cut wood carelessly that grows in the Rangda Hill area. Except for tapakan barong, rangda, pratima, or other holy masks that will be purified. And even then begins with certain rituals or ceremonies.

\subsubsection{Satua Goa Raksasa in Kubusalia Villahe, Bangli Regency}

I Wayan Cana (interview, 15 September 2012) said that the existence of Goa Raksasa (Giant Cave) in Banjar Kubusalia, Sukawana Village, Kintamani District, Bangli Regency. It is told about the Ki Raksasa (Giant) in a village which is now known as Desa Pakraman Kubusalia. But before it became the village of Kubusalia, the village was known as Tubuh village. At that time the villagers would hold a religious ceremony at Bukit Legundi Cemeng Temple. So that all citizens were present in order to prepare all the equipment that will be used.

At that time there were people who prepared upakara, some made Lawar who would be served after the residents finished preparing the ceremonial facilities. Some residents who were scratching coconuts did not care about where they came from, because all were considered family. In the process of making Lawar, there was a resident whose hand was hit by the tool that was scratched, so that the blood mixed with the carded coconut. Lawar which mixed with the blood from person who scratching the coconut was finally eaten by Ki Raksasa in Tubuh village at that era. Because Ki Raksasa felt the Lawar was very delicious with human blood, then Ki Raksasa wanted to prey on humans. 
Once the time came, the ritual of the ceremony was held, which was to coincide with Purnamaning Sasih Kapat. Until now the people in the village of Pakraman Kubusalia are still carrying out ceremonial processions at Pura Bukit Legundi Cemeng. Sasih Kapat (the fourth month in Balinese Calendar) has been known since it has hot weather, the blue sky seems like there isn't a speck of cloud that surrounds nature. During the ceremony, it was said that the Rejang dance was danced by teenager women. Once Rejang dancers began to dance, the nature around the Tubuh village was covered in clouds that were so thick. After the dancers performed the dance, the dancers who danced at the back row disappeared.

The incident happened repeatedly in ancient times in Tubuh village, so that there were initiatives from the villagers for the Rejang dancers who danced on the backmost row of tracks, if they disappeared again, the dancers were given rice, sugar cane, and chicken. The three facilities were thrown away a little, and it turned out that the kidnapper was Ki Raksasa. After the performance, the villagers of the Tubuh village trace were searched. Then the trail was found into the cave which still exists today in the Kubusalia Pakraman village which is located west of the village.

After the residents know where Ki Raksasa lived, all residents negotiated to collect Duk Jaka and some made bamboo spears that would be used to kill Ki Raksasa. The dukjaka was put in the cave in front of the entry point of Ki Raksasa. After placing the duk jaka then in front of Goa the spears were tapered, so that after the Duk and chili was burned, the Ki Raksasa feels hot and finally came out and stepped on the spear. Ki Raksasa's blood until now still has signs on the land. Ki Raksasa condemns all the residents of Desa Tubuh to be Krama Pitu or residents of seven people. Until now the Krama Desa Pakraman Kubusalia when piodalan at pura Bukit Legundi Cemeng amounting to seven people.

The characteristics that can be seen until now from the existence of the Goa Raksasa in Kubusalia Village, Kintamani District, Bangli Regency, are: 1) There is a stone with a size of $40 \mathrm{~cm}$ around which is filled with water that is not full, and used by many residents to bathe endlessly until now; 2) Color of water in the hole of the stone sometimes changes, sometimes clear, sometimes slightly cloudy, sometimes very cloudy; 3) The red land resulting from the splash of Ki Raksasa's blood; and 4) There are a number of non-weathered bone trunks to date their place around the gulf of Subaya village with Kutuh village.

Because of some of the miracles above, this place is protected by the people of Kubusalia, Kintamani District, Bangli Regency.

For example, Balinese folklore, as one of the Balinese myths which have function to protect the environment is not popular anymore these days. There are several things that cause the degradation of its popularity. The society is not able to find the meeting point of knowledge delivered by Balinese folklore with modern knowledge. This gap occurs due to differences in the way the knowledge is obtained. In the world of modern science, knowledge is built on the collection of data from the senses possessed by humans [8]. Whereas in Balinese folklore, knowledge to preserve the environment is built in imaginary stories, which are associated with evidence that is not fully acceptable with common sense. When Balinese society moves into a modern society, the basis for thinking is to follow scientific steps. The educational environment is unable to connect old knowledge in Bali with modern knowledge that is being studied. So of course, the value of environmental conservation that is conveyed in Balinese folklore is not fully capable of controlling individual behavior. Further analysis is needed in the world of education to interpret various values that can be actualized into behavioral patterns from Balinese Folklore.

The ethics of maintaining the environment is actually implied in the Balinese folklore. This can be seen from the behavioral restrictions that are conveyed in the Balinese folklores above. In some cases the connections of myths and knowledge are arranged in the universal rules of 
balance and also Balinese indigenous rules (awig-awig) [9], and the Balinese folklores convey the connection of myths and knowledge that are still relevant to be used as an educational medium outside the rules / awig-awig. Each story in Balinese folklore has its own specialties, according to each local tradition. This situation was then interpreted very rigidly in the traditional knowledge system [10], which then contributed to the gap in the practice of environmental preservation in the modern era with the values implied in the folklore. Therefore, speakers of Balinese folklores are expected to be able to give meaning so that the stiffness generated from the context of the specialties of the local tradition can be decayed or transformed according to the time and need of the community. Balinese folklore has the opportunity to be developed as a learning resource in the context of 21 st century learning, considering that learning requires students to explore new knowledge that are closer to their daily experiences [11].

The ethics of environmental preservation and myths are blended in Satua Bali. It is also actualized into several religious ceremonies, e.g., tumpek ngatag; a ceremony to respect plants, and nunas taru; a ceremony to ask permission to cut down trees for sacred masks. These ceremonies generally aim to limit the felling of trees in an effort to preserve the environment. The fact is that people's behavior in environmental conservation is only limited to the scope of the context of the ceremony, such as only keeping plants growing in sacred areas (around the holy place). For example, the natural conditions in the area of Kubusila, Sukawana, and its surrounding areas are still well preserved, because the myth relating to nature is still strongly believed (Interview, I Wayan Cana on September 14, 2012). The communities around Kubusalia, Bukih, Sukawana, Siakin and others strongly believe in the local diversity in the form of Satua Bali, which contains various stories that remain alive in the frame of people's thinking. The story is believed to be an empirical thought of the ancestors that seemed real and still guided to maintain the continuity of nature. However, when the community lives outside the same setting, the behavior of preserving nature is not done, this should be a reference to always preserve the plants and the environment wherever they are.

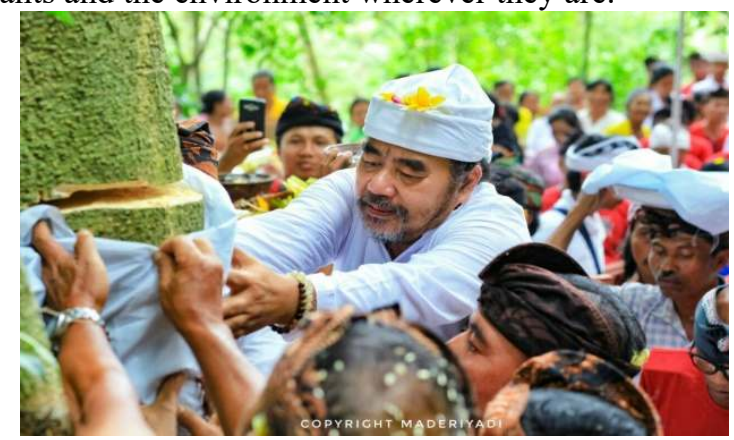

Fig.1 a ceremony to respect plants, and nunas taru; a ceremony to ask permission to cut down trees for sacred masks (sumber; dokumentasi Tanggahan Tengah.blogspot)

Ethnocentric attitudes is in the form of the ethnic members' excessive awareness towards their ethnic group [12], which in the context of Balinese society are built within the Desa Pakraman or Banjar, can be a factor of the rigidity of community members in the meaning of values in satua bali. Balinese local wisdom, which including desa (place), kala (time) and patra (pattern), is one of the references in maintaining harmonious interaction among Balinese people. In the other hand, it is also an obstacle to the actualization of values outside the environmental and cultural context where the Satua Bali is built. This is reinforced by a variety of ceremonies 
or traditions due to differences in the concept of the desa, kala and patra with the same religious teachings. Balinese people's obedience to respect all set of rules or traditions taught outside the caring environment, limits them to actualize values outside their cultural settings. So that, universal values, which should be able to control behavior, are trapped by local concepts that also have significant noble values. Satua Bali teller are expected to have the ability to transform these values, in accordance with the context of the needs of the people in the modern era, so that the myth in Satua Bali can still be a guideline for the behavior of modern Balinese people. In its practice the values in Satua Bali are no longer able to carry out these functions. It happens because there is a rigidity of the meaning of values that both have noble values in Satua Bali and in the context of traditional knowledge [13].

\section{CONCLUSION}

The position of Balinese folklore in the midst of a rapid socio-cultural changes can be said to be very worrying due to the many stories are imported from abroad. There are several Balinese folklores which are still relevant to be used with regard to ecology, namely (a) Satua I Macan di Puncak Mangu Kabupaten Badung, (b) Satua Puncak Rangda, (c) Satua Sawe, (d) Satua Yeh Mampeh, (e) Satua Lipi Selem Bukit, (f) Satua Desa Besan, (g) Satua Lembu Putih Taro, (h) Satua Goa Raksasa. Balinese folklores, especially for the rural communities in Bali, have a function as a media for controlling human behavior toward its environment. However, in its practice, the values conveyed in Balinese folklores are no longer able to carry out these functions, this occurs because there is a rigidity of the meaning of values in Balinese folklores in the context of traditional knowledge. This rigidity must be abandoned and transformed by making Balinese folklore as one of the learning resources to develop critical thinking skills in 21 st century learning.

\section{REFERENCES}

[1] E. Sedyawati, "Kedudukan Tradisi Lisan Dalam Ilmu-Ilmu Sosial dan Ilmu-Ilmu Budaya," War. ATL J. Pengetah. dan Komun. Peneliti dan Pemerhati Tradisi Lisan, vol. II, 1996.

[2] I. G. Ng. Bagus, Nilai Dongeng, Pendidikan, dan Proses Pembudayaannya. Denpasar: Pustaka Sidantha, 1987.

[3] R. H. Hilderbrand, A. C. Watts, and A. M. Randle, "The myths of restoration ecology," Ecol. Soc., 2005.

[4] S. Siti Fatiemah and Z. Jama'yah, "Masa Depan Cerita Rakyat Masyarakat Orang Asli Jakun,” Int. J. Malay World Civilis., 2013.

[5] I. N. K. Ratna, Teori, Metode, dan Teknik Penelitian Sastra. Strukturalisme hingga Postrukturalisme: Perspektif Wacana Naratif. Yogyakarta: Pustaka Pelajar, 2004.

[6] Margaret Poloma, Sosiologi Kontemporer. Jakarta: Raja Grafindo Persada, 2003.

[7] G. Ritzer and D. J. Goodman, Teori Sosiologi Modern. Jakarta: Prenada Media, 2004.

[8] C. Levi-Strauss, "Myth and Meaning," RAIN, 2006.

[9] Aryandari Citra, “'Gringsing' Jalinan Estetika-Mitos Ritus Perang Pandan,” Resital, 2010.

[10] M. Wright, "Myth," in A Companion to Euripides, 2016.

[11] P. Turiman, J. Omar, A. M. Daud, and K. Osman, "Fostering the 21st Century Skills through Scientific Literacy and Science Process Skills," Procedia-Soc. Behav. Sci., 2012.

[12] B. Sibarani, "Bahasa, Etnisitas dan Potensinya Terhadap Konflik," Bahas Unimed, vol. 3, no. 1, pp. 1-10, 2013. 
[13] K. Saddhono, "Cultural and social change of foreign students in Indonesia: The influence of Javanese Culture in Teaching Indonesian to Speakers of Other Languages (TISOL)." IOP Conf. Ser.: Ear. and Envi. Sci.. vol. 126 no. 1 IOP Publishing, 2018. 